\title{
Use of multidisciplinary analysis programs in the design process and its importance in terms of design education
}

\author{
Selçuk Keçel \\ Gazi University, Faculty of Architecture, Ankara, Turkey, kecel@gazi.edu.tr \\ ORCID: orcid.org/0000-0001-9883-0771 \\ Abdullah Toğay \\ Gazi University, Faculty of Architecture, Ankara, Turkey, atogay@gazi.edu.tr \\ ORCID: orcid.org/0000-0002-8703-4881
}

\begin{abstract}
Product design is a sophisticated cyclical process involving different stages, beginning from the problem state to the product end, nested in the process. Also, in the process of design education, the form created by the designer is subjected to various criticisms and is undergoing a change with function relation. The multidimensional thinking skills have been gained to the students during design education cause unique changes on the product. Depending on the dynamic developments, the self-renewing product forms deem it necessary for the designer to be prompted from different sources. Although the factors such as areas of expertise, user needs, production techniques, material choice, and form concern are effective in determining the product identity, the designer presents innovative ideas and solutions to create a "magic touch." This magic touch would contribute identity to the product within this framework. These programs, which contribute to the designers' abilities along with the development of design and analysis programs, are positioned at different intersections in the product design cycle. This situation also has a significant impact on design education. In this study, the effects of these programs, used at different stages of the product design education, on the form were investigated. Moreover, strength examination of the design of the table foot and flow simulation on the hair dryer end apparatus were determined. In two separate multidisciplinary analysis studies, the change in characteristics of the product function with physical interactions was shown. Along with the findings of this research, the contributions of analysis programs on the design process, and the effects to product identity are explained through examples.
\end{abstract}

Keywords Product Design, Product analysis, Identity of designer, Design Education,

\section{Tasarım sürecinde multidisipliner analiz programlarının kullanımı ve tasarım eğitimi açısından önemi}

ÖZ Ürün tasarımı problem durumundan başlanarak ürün sonucuna kadar süren aşamada iç içe geçmiş birbirinden farklı aşamalar içeren karmaşık bir döngüsel süreçtir. Tasarım eğitimi sürecinde de tasarımcı tarafindan oluşturulan form fonksiyon ilişkisiyle beraber çeşitli eleştirilere tabi tutulmakta ve değişime uğramaktadır. Tasarım eğitimi süresince öğrencilere kazandırılan çok boyutlu düşünme becerisi ürün üzerinde özgün değişimlere sebep olmaktadır. Dinamik gelişmelere bağlı olarak kendini yenileyen ürün formları, tasarımcının değişik kaynaklardan beslenme zorunluluğunu da beraberinde getirmektedir. Uzmanlık alanları, kullanıcı ihtiyaçları, üretim teknikleri, malzeme seçimleri, form çabası gibi etmenler ürün kimliğini belirlemede etkili olurken, tasarımcı bu sınırlar çerçevesinde ürüne kimlik katacak sihirli dokunuşlara imza atma çabasıyla yenilikçi fikirler ve çözümlemeler sunmaktadır. Tasarım ve analiz programlarının gelişmesiyle birlikte tasarımcının yeteneklerine de katkı sağlayan bu programlar ürün tasarımı döngüsünde farklı kesişimlerin içinde yer almaktadır. Bu durum tasarım eğitiminde önemli bir etkiye sahiptir. Bu çalışmada ürün tasarımı eğitiminde oluşturulan döngünün farklı aşamalarında kullanılan programların form üzerinde oluşturduğu etki incelenmeye çalışılmıştır. Çalı̧̧mada masa ayağı tasarımında dayanım incelemesi, saç kurutma makinası uç aparatında ise akış simülasyonu yapılmıştır. İki ayrı multidisipliner analiz çalışmasında ürünün fonksiyonunu gerçekleştirecek özelliklerin fiziksel etkileşimlerle nasıl değişime uğradığı gösterilmiştir. Bulgular doğrultusunda analiz programlarının tasarım sürecine sağlayacağı katkılar ve ürün kimliğine etkileri örneklerle açıklanmaya çalışılmıştır.

Anahtar Ürün tasarımı, Ürün analizi, Tasarımcı kimliği, Tasarım Eğitimi,

Kelimeler

Cite This

Keçel, S, Toğay, A, (2017). Use of multidisciplinary analysis programs in the design process and its

Article: importance in terms of design education, Turkish Journal of Education. 6(4), 158-167. DOI: 10.19128/turje.331727 


\section{INTRODUCTION}

Recently, the developing process for Form-Function relation has been launched as a new concept. Over the years, the idea of dealing with future problems during the creation of design products has become more important, and there is a need for working with new methods and techniques. Producing and testing the designed products cause both time loss and increase the product cost (Karamangil, 2007). Therefore, the importance of the work done before the production of the prototype is one criterion regarding both businesses and the position and duties of workers. The continued progress in the areas of expertise involving design products in various scientific branches is remarkable. Particularly, the development in material science, electronic engineering, informatics technologies and the computational design field has completely transformed design. Scientific developments experienced in different areas must reflect the underlying design (Keçel \& Toğay, 2017) (Bayazit, 2013).

'Design' is a multidisciplinary process created by the amalgamation of many concepts. These concepts are properly practiced by designers along with their imagination and experiences. The form of the product undergoes a change of form when the designer realizes the results of the touches he or she has made in all the stages in his mind for solutions based on problems or needs. Design activities provides students to have experience of major profession, to see the applications of the field and to participate in R\&D and P\&D activities (Tekerek \& Tekerek, 2017). Although the effects in working conditions and limitations, generated with the user's needs, seem to be preventive at certain points, the evaluation of different parameters is being experienced in various products bestow distinction and utility upon the product (Keçel \& Toğay, 2017).

In determining the product features, the product form is determined by many criteria within the problemsolving activity depending on the user needs. While making designs for various criteria, there is a need to have a complex order in which people, from various disciplines, and different factors are intertwined with each other. These facts indicate that many methods used in product design are still developing (Küçükerman,1996).

The center of the components within the design processes has also changed in the contemporary meaning. Finally, design is not only designer centered. This situation, as a requirement of the environment of competition, is the result and innovation of the search for advancement of the process of design upon itself. In this process, computer aided design inputs have now emerged from being new and have constituted a significant strength. In the beginning, CAD was defined as a new technology that replaced the drawing tools by many sectors, has gradually increased. In the contemporary sense, CAD is evaluated as a component that feeds creativity and that affects the output of design beyond being only a tool. On the other hand, the place and importance of CAD should be treated and interpreted with extreme care. Robertson et al. said, "CAD has an important role to play, it is but one of many skills needed for a complete design education, and it is one that is in danger of dominating the design education process and the students' conceptions of design" (Robertson et al., 2007).

Innovative applications and analysis programs, which are equivalent to the progress of computer technology, are widely used in many areas. The optimization programs facilitate a designer's work in many ways and contribute to the emergence of inventions with new ideas and improved designs (Christiensen, 2009; Ambrosia, 2009). Particularly in the field of engineering, thermal changes, flow effects, determination of displacement quantities, torsion, and resistance are made using programs with a high percentage of physical change accuracy. Thus, the decision-making process is processed along with resolving any system of thoughts designed before the production phase. Along with the contribution of information technology, processes vary in many stages from modeling to simulation. The center of gravity of the components in the design process has also changed accordingly. Thus, a linear model may become prominent considering the traditional design process definition.

Currently, design programs become parametric and analysis systems adapt to the CAD software infrastructure results in new design environment and tools. The effects of these programs and tools, used often in Industrial Design education and applications, on design thought and practice have been discussed for a long time. In addition to the deliberations in relation with CAD (Computer Aided Design) and FEM (Finite Element Method), within this discussion, both the identity of the designer and evaluation of parameters consistent with technical infrastructure contribute to adoption of a realistic identity in the development of products, which serve the ultimate objective (Keçel \& Toğay,2017). 
On the other hand, design education is aimed at raising individuals who develop original thinking skills, provide simultaneous use of knowledge and skill, and at the same time provide innovative solutions on the product while responding to user needs. In this framework, problems such as problem solving, critical thinking, innovative solutions are tried to be given to designers. With the common points of various fields where the design process is fed, the students are brought to synthesis level and doing product design studies with innovative thinking.

The effects of the analysis and touch that occurred during the formation of the form occurrence in design process in the study were investigated and discussed in terms of design education. In this respect, a system of thinking about the position of multidisciplinary analysis applications in the design cycle has been explained through examples.

This research presents different examples of strength and flow analyses to demonstrate changes that may occur in product form. Thus, the reasons for changes emerging along with the adaptation of various examples in design education are approached using form-function. Thus, the first stage consists of the design of a table-foot connection within the framework of strength analysis. In this design, the way the loads on the table it affects the foot design has been investigated. The optimum design of the foot was realized by revising the form structure. In the second stage, along with the flow analysis, the hair dryer form was considered, the temperature and velocity distributions considering the working conditions of the machine were examined, and then the effects of the designed blowing mouth were investigated. These findings, along with the changes in the results of hot air distribution, helped make an optimization. Thus, the "basics of incorporating analysis programs into the design process", which are fundamental to the research, are discussed.

Within this framework, static stress module in the Fusion program and Fluent module in the ANSYS program were used. In this study, a cycle that can calculate the relation between the limitations of the technical parameters and the design decisions in the design process has been explained.

\section{METHODOLOGY}

\section{Finite Element Method}

The Finite Element Method is a process due to the division of physical environment into finite particles, and then the determination of changes sought in the system by the behavior of these finite particles under certain circumstances. The most important parameter needed to get accurate results at this stage is the complete modeling of all parts along with the similarity of the product with reality. By using the finite element method with various analyses, certain behaviors - just before the production - are observed (Conle, 1997; Fatemi \& Kurat, 1998; Taylor et al., 2000). In this research, the finite elements method constitutes the basis of the Static stress module which was used in the analysis of table foot. Basically, the geometry that emerges in mind in the design process that started with sketch drawing is transferred to this model. Moreover, the changes occurring in the working environment of the product are analyzed according to this method.

In the Finite Element Method, the solution steps establish the model, and thus, divide the system - whose geometry is determined - into elements compatible with the desired result, the definition of the boundary conditions, and external loads into the system and solution. The engineering problems intended to be solved by the Finite Systems Methodology should consist of a finite number of separate elements connected to nodes. If force displacement equations can be established for each element, they can also be established for the entire system. Systems created using the finite element method can be constructed using the time-varying or unchanging characteristics (Vural, 2009). Some package programs use the algorithms of the Finite Element Method to solve the engineering problems of different disciplines such as Ansys, Autodesk, Marc, Abaqus.

\section{Finite Volumes Method}

This method was used in the analysis of the dryer apparatus analyzed in the Ansys-Fluent module as multidisciplinary analysis programs. Specifically, this method would be beneficial in the development of fluid (water and air) based products. The ideas generated by the designer may produce results concerning physical parameters, but this is especially difficult to predict in products with fluid interaction. For this purpose, the replacement of the function based form sample to be presented on the drying machine will also be concluded with this method. 
There are various methods for examining fluid motion. Calculation methods utilized to examine fluids can be grouped into Computational Fluid Dynamics (CFD). In addition to Computational Fluid Dynamics or CFD, the systems involving fluid motion, heat transfer and various related problems are modeled and analyzed in computers (Versteeg \& Malalasekara, 2007) (Ansys, 2011). This technique has a very wide and powerful usage area in industrial and non-industrial application fields. CFD consists of three basic steps: pre-process, solution and post-process (Çengel \& Çimbala, 2008). The preprocessing phase includes inputs made by the user to CFD programs for the solution of the fluid problem. These are the definitions of solution domain geometry, separation of solution domain into subelements and network formation, selection of the physical model, the definition of flow properties, and determination of boundary conditions on elements (Ansys, 2011). There are three different techniques in the solution phase. These techniques are Finite Difference Method, Finite Element Method, and Boundary Element Method. The Finite Volume Method was found to be especially developed by the formulations of the Finite Difference Method. The main steps of the solution step by the numerical methods are the identification of unknown current values regarding simple functions, separation by the implementation of approaches to the equations directing flow, mathematical operations, and the solution of the sets of algebraic equations (Çengel \& Cimbala, 2008). The final stage of the process is the representation of the results obtained from the solution in various forms. These are revealed as a demonstration of domain geometry and network structure, vectoral drawing, 2D or 3D drawings, particle monitoring and colored prints (Versteeg \& Malalasekara, 2007).

\section{MULTIDISCIPLINARY ANALYSIS APPLICATIONS}

\section{Strength Analysis}

In the context of strength analysis, the "table foot connection" example has been processed, and the process has been carried out for the innovative design of the foot in connection with a holistic table design. Analyses started with the modeling of the foot connection and continued with the focus on the effects of loads on the product. The aim is to make an optimal design depending on the physical parameters before prototyping by considering strength, elasticity and displacement ratios. The design process takes place in a cycle in which the user requirements are defined along with the data, the working conditions and limitations restrain the design decisions, the answers and decisions are made by the designer according to the analysis results, and the obtained analysis data influences form decisions.

\section{Table-Foot Connection Design}

Thus, for designing a foot connection for office furniture, the form both aesthetically completes the product and exists in a sustainable structure consistent with strength relations. An office table design was made on an aluminum alloy carrier system under static load. In this context, because of the pursuit of a form, the product was subjected to static analysis in the basic structure consisting of 2 feet and interconnection elements. The basic inputs for the analysis processes are given in Figure 1.
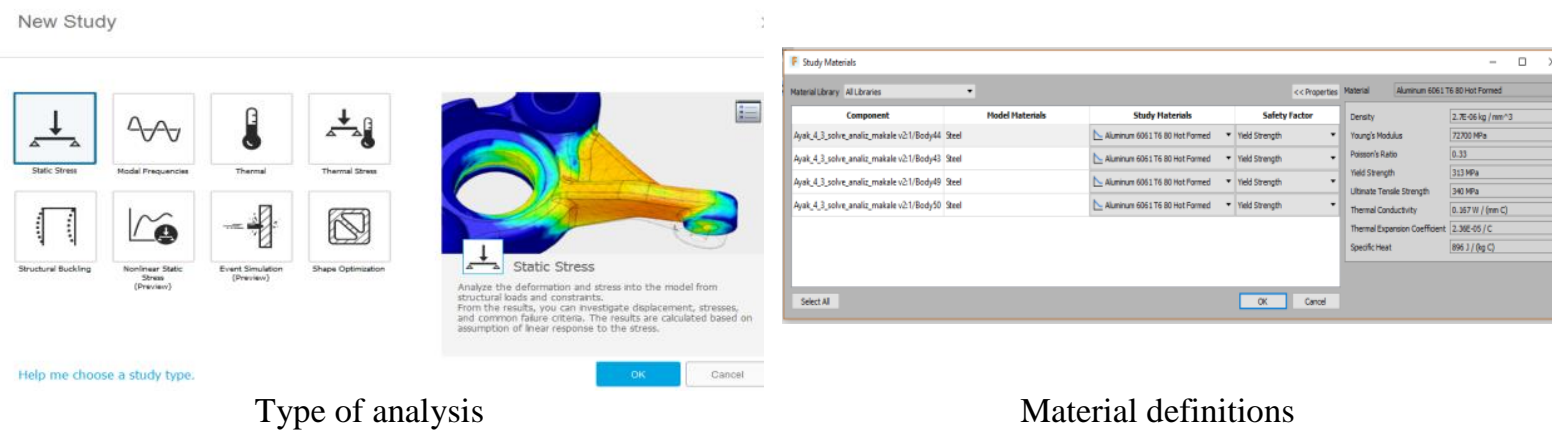

Figure 1. Autodesk-Fusion Analysis process

The initial system of ideas of the designer is modeled and reflected into a program intended for the relationship between form and function. In the following stage, the loads applied to the table in real conditions were calculated and implemented at correct points within the program. Moreover, the 
material characteristics were selected in the program cycle, and the quality values of the nodes for a correct analysis were noted to be high.

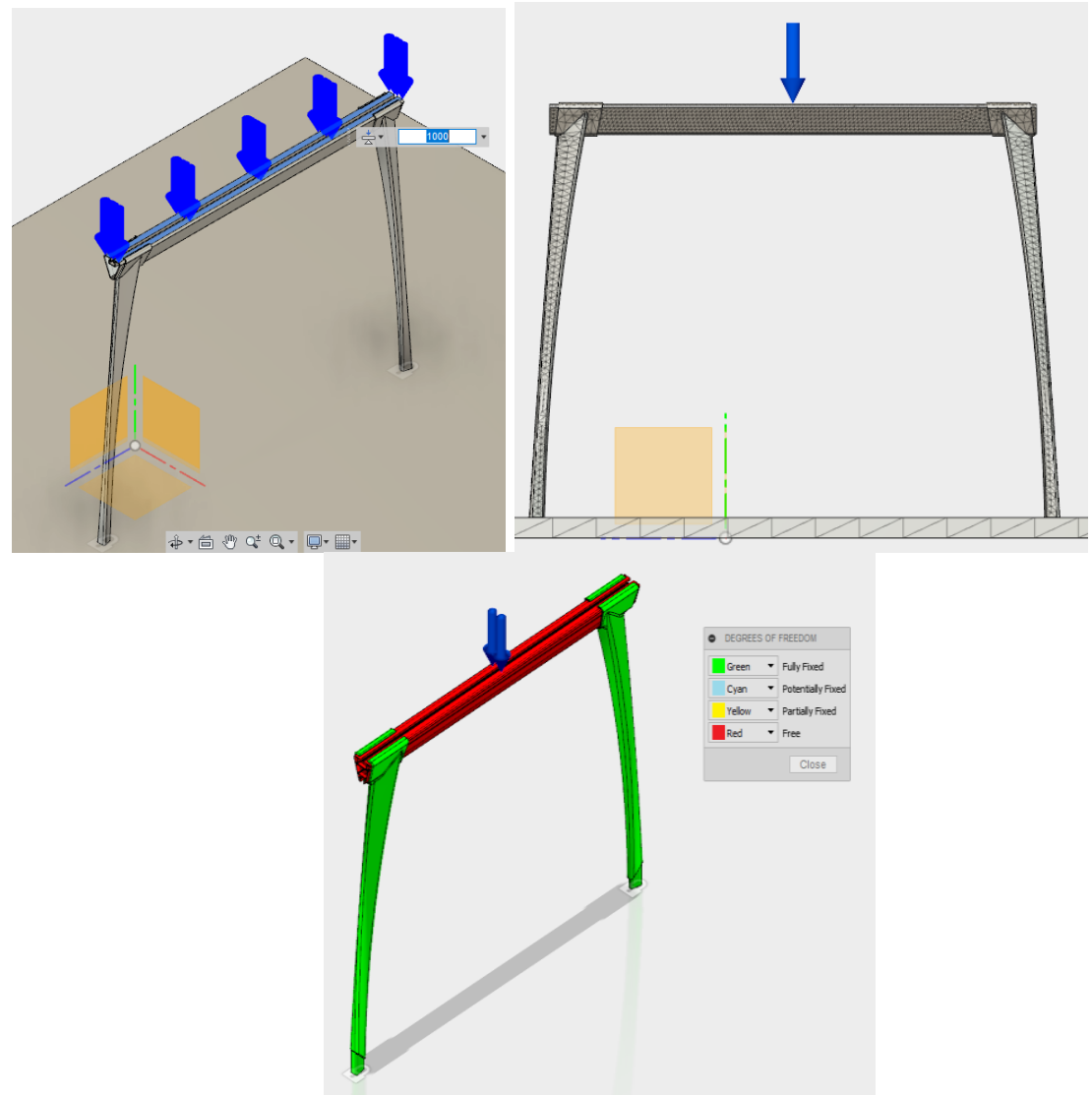

Figure 2. Load line and size $(1000 \mathrm{~N})$ and meshing operations

Free condition given to product components and the image of network structure created according to the preferred mesh settings are shown in Figure 2. The analysis results obtained from the Autodesk-Fusion Static Stress module regarding material properties and appropriate boundary conditions are shown in Figure 3.
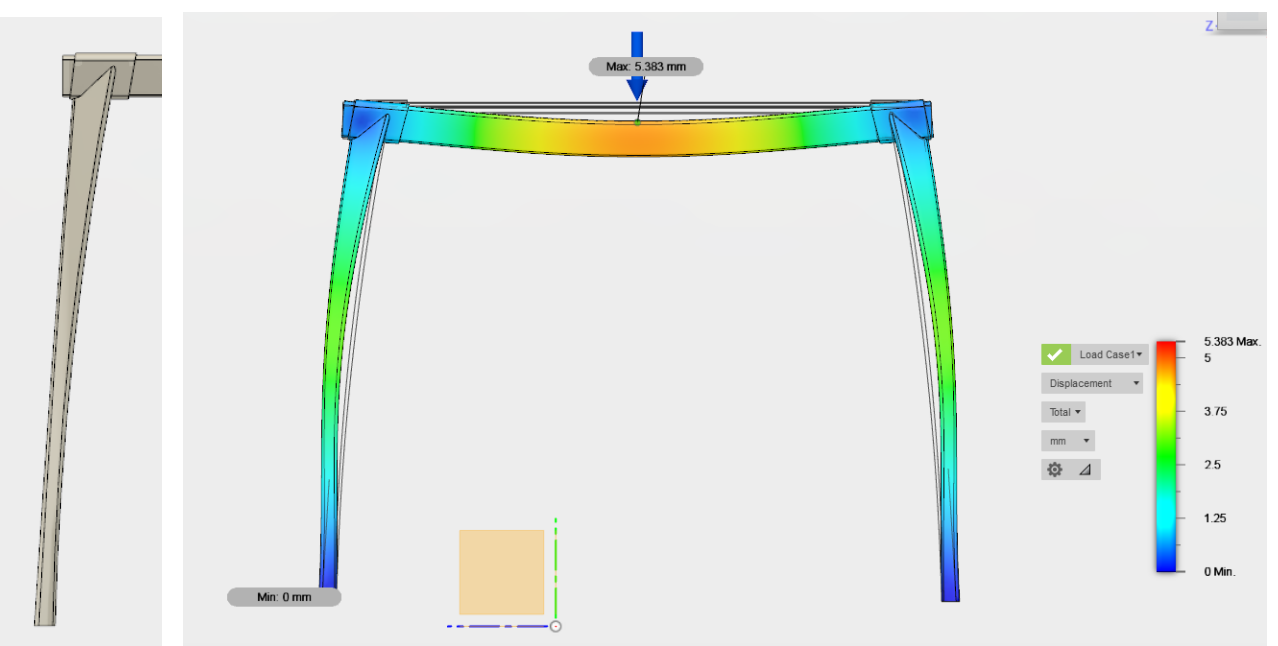

Figure 3. Displacement values on the initial stage form (mm)

Findings show that displacement amount is $5 \mathrm{~mm}$ for initial design. It was clearly seen that the values obtained according to the strength of this material and its displacement amounts were above the working limits and underwent deformation. The evaluation of the data obtained in the previous step in the design 
cycle and the effect of the decisions taken as a result is the basis for the next step. In this respect, the different form structures obtained in the mind of the designer are reconstructed and remodeled regarding evaluation of the effect to be revealed. The image and analysis results of new form are shown in Figure 4.

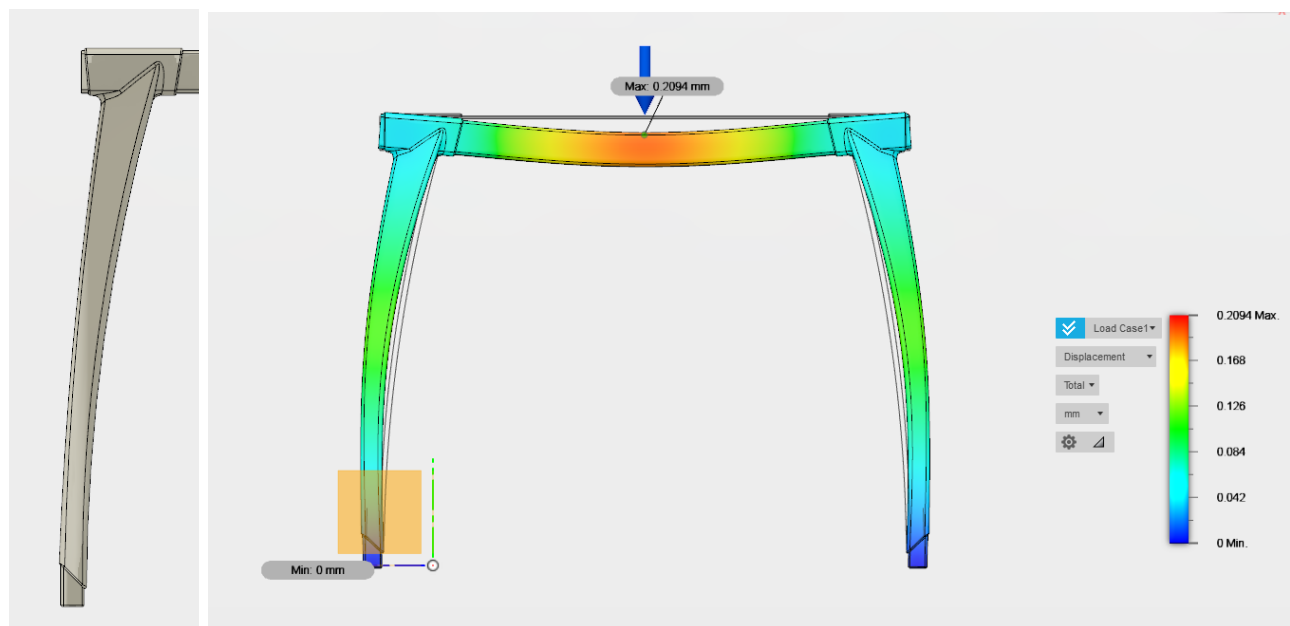

Figure 4. Ultimate stage form and displacement values on this form (mm)

The results of the first analysis showed the occurrence of up to $5 \mathrm{~mm}$ displacement. The material choice was evaluated based on its effect on production and cost, and it was maintained constant. In this context, the material needed is defined by the changes, which increase its endurance in the cross section of the product. The foot form was redesigned, and the product form was changed and analyzed. At the end of an iterative process, the design was terminated at the point where material deformation was within the expected limits (Figure 4) (approximately 0.3mm). In Figures 3 and 4, the changes in the initial and final foot form and design were observed. Therefore, there was an expansion in the foot, in variable sections, and the optimal form of ideal behavior was obtained. The layered part, created as the decision of the designer at the ground-touching part of the ultimate stage form did not affect the analyzed displacement values.

Considering the strength analysis, the data on the models and behaviors that were formed after the first form study were reviewed and the foot connection was observed to create problematic parts at different points. Nevertheless, it was observed that the designer produces an innovative idea, which will result in less displacement and deformation in the same material and boundary conditions in the second model, which is produced by considering the obtained data. At this stage, important changes take place on the form with multidisciplinary applications in the design, which provides product integrity along with aesthetic and strength criteria. Within the framework of the obtained strength analysis it is thought that it is important to use these types of programs in design training, especially when designing products with load connections.

\section{Flow Simulations}

In the frame of the flow analysis, the "hair dryer end apparatus development" example was performed. Moreover, the flow and temperature values obtained at the end of the process flow analysis were retrospectively continued until a homogeneous distribution was established. The air flow part of the hair dryer was modeled, and the distribution of the indoor air flow was investigated. The change in the end part of the apparatus was examined within the form of a hair dryer. According to the speed values obtained, the form change was made at the end part according to the state of homogeneous drying. The form for the hair dryer is shown in Figure 5. 

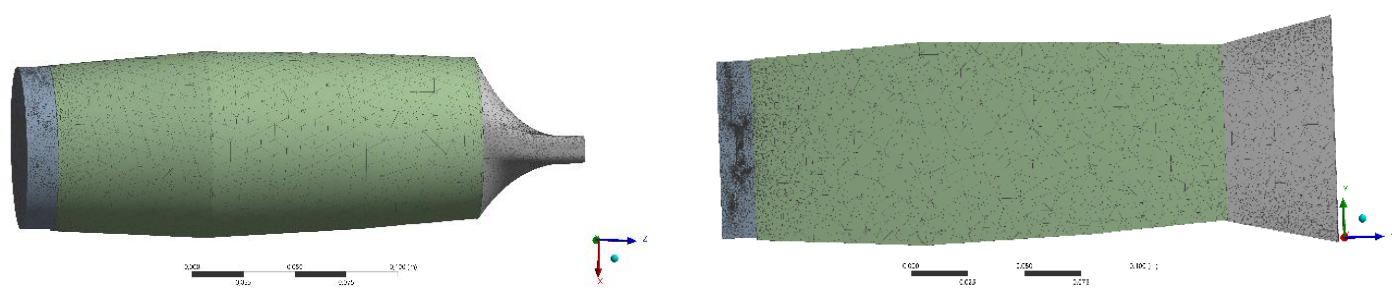

Figure 5. Flow volume and meshing structure of the dryer

Two different models were designed for different mouth structures for the attachment device located at the end of the holistic form. Views of these models are shown in Figure 6.

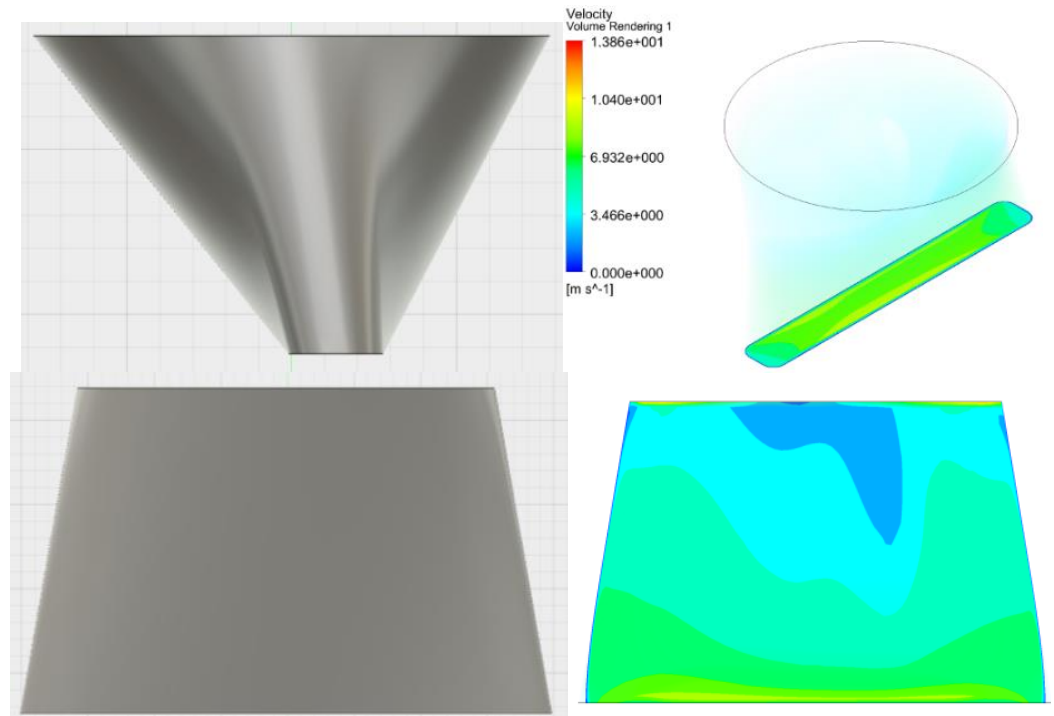

Figure 6. First stage drying machine mouth form and velocity values

The results of the part design at the end of the machine were examined in the model, which was prepared to predict the form and function. Thus, model geometries are made to be compatible with working conditions. The distribution results obtained from this preparation are shown in Figure 7. The operating conditions of a hair dryer with turbo include a flow capacity of approximately $78.3 \mathrm{~m}^{3} / \mathrm{h}$, and the air outlet speed should be $11 \mathrm{~m} / \mathrm{s}$.

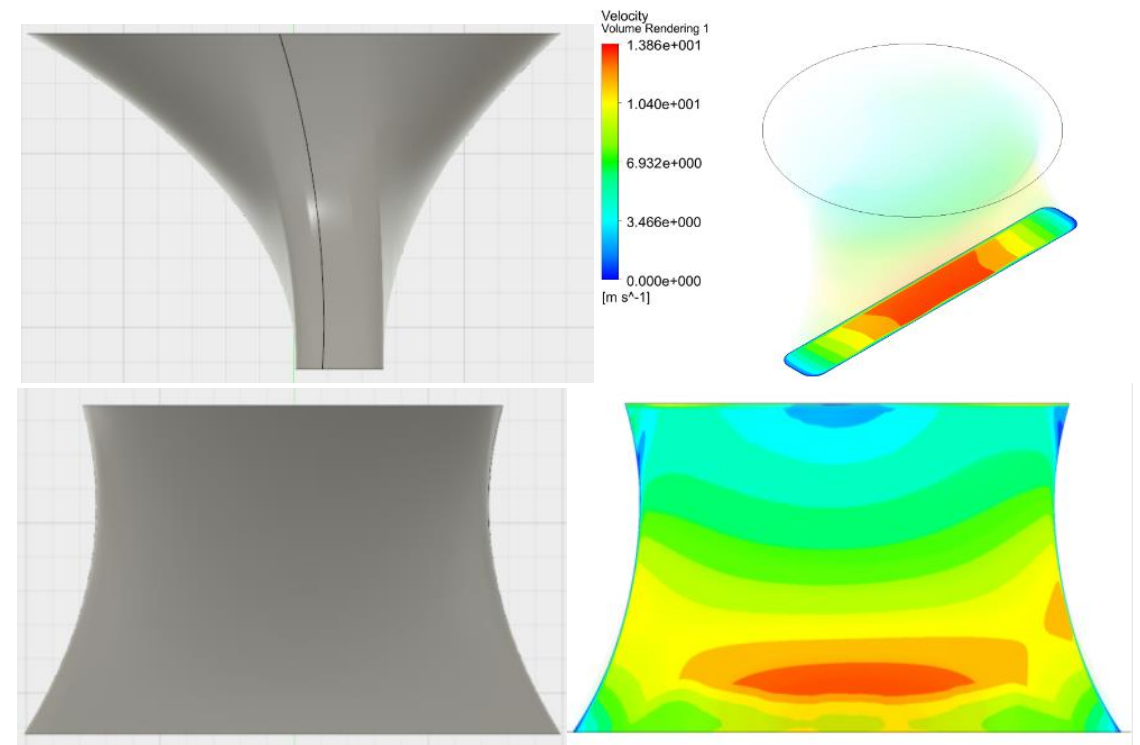

Figure 7. Final stage drying machine mouth form and speed values 
The flow values obtained from the last design are observed to be in accordance with the flow capacity parameter. Moreover, there are zonal homogeneous distributions at the exit speeds according to the form structure determined by the designer. In this respect, the form given by the designer shows different characteristics in the same examination values. Analyses made for this purpose benefit the development of a stronger identity regarding the development of different ideas and creative thinking in the designer. In addition to the aesthetics and enabling product integrity in the designer's mind, air flow behaviors provide benefit at the stage of devoting identity to the product.

An optimal mouth design was made before prototyping for providing homogeneous distribution through physical parameters in flow analysis. Moreover, analysis-assisted designs according to the additional user should be developed in drying machines. These designs will have positive results for both producers and consumers and would offer significant opportunities to designers. It is thought that the use of analysis programs should be included in view of physical effects that designers will see in fluid-based products in design education.

\section{CONCLUSION}

In the product design process, the process that begins with the form passes through different stages and is brought up to the product stage by the designer. The product is subjected to many tests about prototyping and production methods with physical working parameters. The application results obtained at the end of this process play an important role in reshaping the product by integrating with time, cost and knowledge. In the design cycle, the decisions made by the designer before prototyping, considering the production or physical conditions, might bring significant gain to the enterprises. Thus, participation in the process of direct impact analysis programs, in the product design process, will benefit both the product and the identity development in the designer. In this study, the changes in the form perception of multidisciplinary analysis applications in the design process of function based products were investigated. In two separate analysis programs, the behavior of products having different functions was examined in accordance with the working conditions. After the form of the table-foot connection was designed to be aesthetically compatible, it was subjected to loading according to the material characteristics. A deformity of about $5 \mathrm{~mm}$ was noted. Therefore, re-form design was carried out, and the amount of deformation was reduced to the level of $0.2 \mathrm{~mm}$. In the second analysis, a new form design was made by observing that the apparatus for the tip of the hair dryer was designed and it did not reach the desired air velocity and or exhibit a homogeneous distribution. Air flow rates were verified by considering the capacity flow rates produced by the hair dryer and homogeneous distribution was ensured. Thus, the changes made in form according to both the strength function and the flow function are supported by the analysis programs indicating that the product has been tested and optimized before it reaches the prototyping stage. These results are presented through examples that analyze programs which have strengthened the identity of designers and also influence design decisions. Consequently, the use of multi-disciplinary analysis programs in the processes of strengthening designer identity and designing high-performance products was established. On the other hand, it can be said that these developments will affect many processes including design education. It is recommended that this perspective should be evaluated within the education system and this approach should take place in the curriculum.

\section{REFERENCES}

Ambrosio J., A.C. \& Eberhard P. (2009). Advance Design of Mechanical Systems: From Analysis to Optimization, Springer Wien, New York, 303-314.

ANSYS, Inc. (2011). Fluent Theory Guide, South pointe 275 Technology Drive Canonsburg, USA November, $57-65$.

Bayazıt, N. (2004). Design Theories and Methods, Birsen Publishing House, İstanbul, 60-65.

Christensen P., W. \& Klarbing A. (2009). An Introduction to Structural Optimization, Springer, Sweden, 179-193.

Conle, F. A. \& Chu, C. C. (1997). fatigue analysis and the local stress-strain approach in complex vehicular structures, International Journal of Fatigue, 19(1), 317-323.

Çengel Y. \& Cimbala J.M. (2008). Fluid Mechanics Basics and Applications, Güven Scientific, İzmir, 15-345.

Fatemi, A. \& Kurath, P. (1988). Multiaxial fatigue life predictions under the influence of mean stresses, J. Engn Mater. Techn., 110, 380-388. 
Karamangil, M.I. (2007). Fatigue analysis of the rear axle of a car with finite element method, Pamukkale University Journal of Engineering Sciences, 13 (3), 311-318.

Keçel S. \& Toğay A. (2017). Using finite volumes method in product design - fan to surface cleaning device, Online Journal of Art and Design, 5(3), 22-37.

Keçel S. \& Toğay A. (2017). Analysis Based Evolutionary Design: Surface Cleaning Device Example, The Turkish Online Journal of Design, Art and Communication, 7(2), 163-174. DOI:10.7456/10702100/002

Küçükerman, Ö. (1996). Industrial Design, Creativity in Product Design for Industry, Yem publishing, İstanbul,15-22.

Robertson, B. F., Walther, J. \& Radcliffe, D. F. (2007). Creativity and the use of CAD tools: lessons for engineering design education from industry, ASME. Journal of Mechanical Design, 129(7), 753-760.

Tekerek, M, Tekerek, B. (2017). Emotional intelligence in engineering education. Turkish Journal of Education, 6 (2), 88-95. DOI: 10.19128/turje.306499

Taylor, D., Bologna, P. \& Knani K. B. (2000). Prediction of fatigue failure location on a component using a critical distance method, International Journal of Fatigue, 22, 735-742.

Versteeg H.K. \& Malalasekera W. (2007). An Introduction to Computational Fluid Dynamics the Finite Volume Method, Pearson Prentice Hall Second edition, 16-200.

Vural U. (2009). Analysis of Distortions After Welded Manufacturing by Finite Element Method, (Unpublished master's thesis), ITU Institute of Science and Technology, İstanbul, 29-32. 


\section{TÜRKÇE GENIŞLETILMIŞ ÖZET}

Tasarım birçok kavramın bir araya gelmesi ile oluşan multidisipliner bir süreçtir. Bu kavramlar tasarımcıların ellerinde, hayal güçleri ve tecrübeleri ile birleştirilerek doğru bir biçimde hayata geçirilir. Tasarımcı problem/ihtiyaçlara dayalı çözümler için zihninde canlandırdığı tüm evrelerde yaptığı dokunuşlara ait çözümlemelerin ne tür fayda/zarar getireceğine dair düşünceleri okumaya başladığında forma ait oluşan ürün olgusu değişme uğramaktadır. Bu çalışma ürün tasarımı eğitiminde formfonksiyon ilişkisinin fiziksel çalışma koşullarına bağlı olduğu ürün gruplarında multidisipliner analiz programlarının kullanımı üzerine kurgulanmıştır. Tasarımcı tarafından kullanıcı ihtiyaçalarına cevap verebilmek aynı zamanda pazarda yer alabilecek bir ürün oluşumuna katkı sağlayacak fikirler henüz form aşamasında olgunlaştırılmaktadır. Tasarımcının fiziksel çevreyle uyumlu bir şekilde çalışması ise zaman ve maliyet kavramlarından tasarruf edilmesine imkân sağlayacaktır. Bu açıdan gün geçtikte ilerleyen parametrik ve çok amaçlı analiz programlarının kullanımının yaygınlaşmasının doğuracağı etkiler bu çalışma kapsamında yordanmıştır. Temelde problem durumuna ait ortaya atılan ilk formun doğruluğu tasarımcı açısından önemli görülmekte ve ürünleşme sürecine kadar farklı etkiler ile değişime uğrayarak son halini almaktadır. Ürünler bulundukları çalışma ortamlarındaki fiziksel etmenlere bağlı olarak termal değişimler, akış etkileri, yer değiştirme miktarlarının tespiti, burulma, dayanım gibi birçok fiziksel değişime uğramaktadır. Bu çalışmada ürün tasarımı döngüsünde form aşamasında analiz programlarının kullanılmasının form değişiminde yarattığı etkiler araştırılmıştır. Bu çalışma ürün formunda meydana gelebilecek değişimleri göstermek amacıyla dayanım ve akış analizlerine ilişkin farklı örnekleri sunmaktadır. Çalışma yöntemi olarak birçok fiziksel değişimin incelendiği sonlu elemanlar ve sonlu hacimler metodundan yararlanılmıştır. Temel olarak Sonlu Elemanlar Yöntemi, fiziksel çevrenin sonlu parçacıklara ayrılması, daha sonra bu sonlu parçacıkların belirli etkenler altındaki davranışlarından yola çıkılarak ilgili sistemde aranan değişimlerin belirlenmesinden meydana gelmektedir. Bu aşamada doğru sonuçlar elde edebilmek için gerekli olan en önemli parametre ürünün gerçeğe olan benzerliği ile tüm parçaların eksiksiz olarak modellenmesidir. Dayanım analizi çerçevesinde "masa ayak bağlantısı" örneğine gidilmiş, süreç bütünsel bir masa tasarımı içinde yer alan ayak bağlantısının yenilikçi tasarımına yönelik gerçekleştirilmiştir. Analizler ayak bağlantısının modellenmesi ile başlanarak, üzerinde oluşacak yüklerin ürüne nasıl bir etki yapacağı üzerinde yoğunlaşılarak devam etmiştir. Dayanım, esneme ve yer değiştirme oranlarına bakılarak prototipleme öncesi fiziksel parametrelere göre optimal bir tasarım yapılması hedeflenmiştir. Tasarım sürecinin kullanıcı ihtiyaçlarının verilerle tanımlandığı, çalışma koşul ve sınırlılıklarının tasarım kararlarına ait sınırlılıklar çizdiği, yanıtları ve kararları analiz sonuçlarına göre tasarımcının verdiği, elde edilen analiz verilerinin form kararına etkidiği bir döngüde gerçekleşmiştir. Dayanım analizlerine bakıldığında ilk form çalışması sonrasında oluşturulan model ve davranışlara ilişkin veriler gözden geçirilmiş ve ayak bağlantısının farklı noktalarda problemli bölgeler oluşturduğu görülmüştür. Bununla birlikte tasarımcının elde edilen verileri göz önüne alarak ürettiği ikinci modelde aynı malzeme ve sınır şartlarında daha az yer değiştirme ve deformasyona sebep olacak yenilikçi bir fikir ürettiği görülmüştür. Akış analizi çerçevesinde "saç kurutma makinası uç aparatının geliştirilmesi" örneğine gidilmiş, süreç akış analizi sonunda elde edilen hız ve sıcaklık değerleri ile yeniden gözden geçirilerek homojen dağılım oluşturuluncaya kadar devam ettirilmiş̧ir. Saç kurutma makinasının hava akış kısmı modellenmiş, iç hava akışının nasıl bir dağılım ortaya çıkardığı incelenmiştir. Saç kurutma makinası formunda uç kısım aparatının değişimine bakılmış, ortaya çıkan hız değerlerine göre homojen bir kurutma yapma durumuna göre uç kısmında form değişikliğine gidilmiştir. Elde edilen hız değerlerine bakıldığında debi parametresi ile uyumlu olduğu aynı zamanda tasarımcı tarafından belirlenen form yapısına göre çıkış hızlarında ve bölgesel homojen dağılımlar olduğu görülmektedir. Bu açıdan tasarımcının verdiği form aynı çalışma değerlerinde farklı karakteristik özellikler göstermektedir. $\mathrm{Bu}$ amaçla yapılan analizler daha güçlü kimlik oluşturulması aşamasında tasarımcıya farklı fikirler ve yaratıcı düşünce geliştirilmesi açısından faydalar sağlamaktadır. Tasarımcının estetik ve ürün bütünlügünü sağlama düşüncesine ilave olarak hava akışının davranışları ürüne kimlik kazandırma aşamasında yarar sağlamaktadır. Ürün Tasarım sürecinde form ile başlayan süreç farklı aşamalardan geçerek tasarımcı tarafından ürün aşamasına kadar getirilmektedir. Prototipleme ve üretim yöntemleri ile fiziksel çalışma parametreleri göz önüne alınarak ürün birçok teste tabi tutulmaktadır. $\mathrm{Bu}$ süreç sonunda elde edilen uygulama sonuçları zaman, maliyet ve bilgi birikimi ile bütünleşerek ürünün yeniden şekillendirilmesinde önemli rol oynamaktadır. Tasarım döngüsünde tasarımcının üretim veya fiziksel koşulları göz önüne alarak 
prototipleme öncesinde vereceği kararlar yine işletmelere önemli kazanımlar sunacaktır. Bu açıdan ürün tasarım sürecine doğrudan etkiyecek analiz programlarının sürece katılması hem ürün hem de tasarımcı kimliğinin geliş̧imine fayda sağlayacaktır. Bu çalışmada özellikle fonsiyona dayalı ürünlerin tasarım sürecinde multidisipliner analiz uygulamalarının form algısında yaratacağı değişimler incelenmiştir. İki ayrı analiz programında farklı fonksiyonlara sahip ürünlerin davranışları çalışma koşullarına uygun olarak incelenmiştir. Masa ayak bağlantısına ait form estetik açıdan uyumlu olacak şekilde tasarlandıktan sonra malzeme özelliklerine göre yüklemeye tabi tutulmuş ve $5 \mathrm{~mm}$ kadar deforme olduğu görülmüştür. Bu sonuca ilişkin olarak yeniden form tasarımına gidilmiş ve deformasyon miktarı $0.2 \mathrm{~mm}$ seviyesine çekilmiştir. İkinci analizde saç kurutma makinasının uç kısmına ait aparat tasarımı yapılmış hem istenen hava hızına ulaşmadığı hem de homojen bir dağılım sergilemediği görülerek yeni bir form tasarımı yapılmıştır. Saç kurutma makinası tarafından üretilen debi miktarları gözönüne alınarak hava çıkış hızları doğrulanmış ve dağılımın homojenleşmesi sağlanmıştır. Böylece hem dayanım fonksiyonu hem de akış fonksiyonuna göre formlarda yapılan değişiklikler analiz programları ile desteklenmiştir. Dolayısıyla her iki ürün prototipleme aşamasına gelmeden test edilerek optimize edilmiştir. Tasarım süreçlerindeki bu değişimin tasarım eğitimi de dâhil olmak üzere birçok alanı etkileyeceği söylenebilir. 